\title{
GARY STANLEY BECKER. EKONOMIA JAKO SZTUKA NAJLEPSZEGO WYKORZYSTYWANIA ŻYCIA
}

\author{
Artur Domurat \\ Akademia Leona Koźmińskiego
}

Dlaczego kolejne pokolenia spędzają w szkole więcej czasu niż poprzednie? Dlaczego, wbrew przewidywaniom Malthusa, mimo rosnącej liczby ludzi na świecie i ograniczonych zasobów, ogólnie nie spada poziom życia? Dlaczego w zamożniejszych społeczeństwach ludzie odwlekają decyzję o założeniu rodziny i chcą mieć mniej dzieci? Jak to jest, że zaostrzanie kar za recydywę, zamiast zapobiegać przestępstwom, prowadzi do ich brutalizacji? Co mają wspólnego ze sobą: zwlekający z publikacją badacz, gromadzący wciąż literaturę i dane, nastolatek, którego trudno oderwać od smartfona, i miłośnik sportów ekstremalnych, notorycznie ryzykujący życiem?

Wyjaśnianie takich decyzji, z ekonomią na pozór niemających nic wspólnego, stanowiło przedmiot twórczości naukowej Gary'ego Stanleya Beckera, laureata Nagrody Nobla w dziedzinie ekonomii z 1992 roku, przyznanej mu „za rozszerzenie zastosowań analizy ekonomicznej na szeroki zakres ludzkich zachowań i interakcji, którymi wcześniej, o ile w ogóle, zajmowały się inne nauki społeczne, takie jak socjologia, demografia i kryminologia”. Przekonanie Beckera o możliwości uniwersalnego zastosowania analizy ekonomicznej najlepiej oddaje, często przezeń przytaczany, aforyzm G.B. Shawa: „Ekonomia jest sztuką jak najlepszego wykorzystywania życia” (np. motto w: Becker, 1976; por. tytuł: Becker, 1992).

\section{ŻYCIORYS: NIEOCZYWISTE POCZÅTKI}

Gary Stanley Becker urodził się 2 grudnia 1930 roku w Pottsville, mieście górniczym w Pensylwanii, a zmarł 3 maja 2014 roku w Chicago. Jego dzieciństwo i młodość raczej nie zapowiadały późniejszych osiągnięć. W wykładzie noblowskim Becker wspominał siebie jako typowego nastolatka z Brooklynu, zainteresowanego bardziej sportem niż nauką. W domu miał niewiele książek, a gdy jego ojcu, współwłaścicielowi niedużego biznesu, pogorszył się wzrok, czytał mu bieżące informa- 
cje finansowe i notowania giełdowe z gazet. Nudziło go to, ale stanowiło pretekst do ciekawych dyskusji o polityce i sprawach społecznych. Również na studiach bardziej interesowały go socjologiczne wyjaśnienia codziennych decyzji niż ekonomiczny świat tabel i cyfr. Studiując matematykę na Uniwersytecie w Princeton, dość przypadkowo zapisał się na wykłady z ekonomii, podczas których zaintrygował go matematyczny rygor analiz ekonomicznych. Sama ekonomia wydawała mu się nieciekawa, gdyż nie zajmowała się istotnymi problemami społecznymi. Stosunek Beckera do ekonomii ewoluował podczas studiów magisterskich i doktorskich, realizowanych pod kierunkiem Miltona Friedmana na Uniwersytecie w Chicago. Zatrudniony tam później na stanowisku adiunkta do roku 1957, Becker zajmował się uprzedzeniami i dyskryminacją na rynkach pracy i dóbr konsumpcyjnych. Kolejne dwanaście lat spędził na Uniwersytecie Kolumbii i w Narodowym Biurze Badań Ekonomicznych w Nowym Jorku, pracując nad kapitałem ludzkim, alokacją czasu i ekonomiką pracy. W roku 1970 Becker wrócił na Uniwersytet w Chicago i pozostał tam już do końca swojej kariery. Prowadził badania nad ludzkimi wyborami w różnych dziedzinach, w tym nad ekonomią polityki i rodziny.

Becker był dwukrotnie żonaty. Z Dorią Slote, która zmarła w roku 1970, miał dwie córki. Guity Nashat, historyk Bliskiego Wschodu, Becker poślubił w roku 1980. Poznali się przypadkowo, gdy badacz sprzedawał tekowe meble. Obejrzawszy je pod nieobecność Beckera, rozczarowana jakością, Nashat próbowała przez telefon wynegocjować niższą cenę. Becker okazał się równie stanowczy, co mało empatyczny: wyjaśnienia, że meble są niezgodne z oczekiwaniami, skwitował radą, żeby znalazła sobie coś, co lubi; tłumaczenia, że nie ma czasu szukać, a z natychmiastową zapłatą i odbiorem ma problem, skomentował, że jej kłopoty go nie obchodzą i może nie płacić, ale niech bierze te meble od razu albo wcale. Przyszła żona i współpracowniczka była zdziwiona: co to za ekonomista, który nie zgadza się obniżyć ceny, ale pozwala obcej osobie wziąć rzeczy bez zapłaty. Becker wyjaśnił jej później, że nie chodziło mu o pieniądze, lecz o zasadę, że nie należy sprzedawać rzeczy poniżej ich wartości rynkowej (Levitt, 2006).

\section{HOMO OECONOMICUS I STOSUNEK BECKERA DO EKONOMII BEHAWIORALNEJ}

Gary Becker w naturalny sposób podzielał paradygmat badawczy szkoły chicagowskiej, znanej ze sceptycyzmu wobec interwencji rządu - przekonania, że za inflację odpowiada ilość pieniądza obecna na rynku oraz wiary w wolny rynek jako najefektywniejszy mechanizm organizowania zasobów. Twierdził on np., że „nawet czarodziej miałby duże trudności z uchyleniem prawa ekonomicznego, polegającego na tym, że wyższe płace minimalne zmniejszają zatrudnienie. Ponieważ politycy 
nie są czarodziejami, nie powinni próbować tego robić" (Becker i Nashat, 1997, s. 38). W przeciwieństwie do szkoły austriackiej, również wolnorynkowej, badacze nurtu chicagowskiego korzystali z analizy matematycznej, wyprowadzając niedostrzegane uprzednio zależności ekonomiczne i weryfikując je danymi gospodarczymi. O ile jednak współpracownicy Beckera nie wykraczali poza analizę „typowych” rynków, ten stwierdził, że praktycznie każdy aspekt ludzkiego zachowania można poddać analizie ekonomicznej, ponieważ przedmiot nauk społecznych, takich jak socjologia, psychologia czy ekonomia, jest w istocie rzeczy ten sam. Tym, co różni te dziedziny, jest metodologia.

Sednem podejścia ekonomicznego Beckera są trzy założenia, które konsekwentnie przyjmował i których nigdy nie porzucił: o maksymalizacji użyteczności, o istnieniu stabilnych preferencji decydenta oraz o dążeniu rynku do stanu równowagi (Becker, 1976, s. 14-15). Ludzie maksymalizują użyteczność, szeroko rozumiane korzyści lub dobrobyt. Ludzkie preferencje są stabilne i to ludzie najlepiej sami wiedzą, czego chcą. Jak napisze w późniejszych latach wraz z G. Stiglerem, „o gustach się nie dyskutuje" (Stigler i Becker, 1977). Ludzie mają prawo formułować cele i wartości zgodnie z własnymi preferencjami, natomiast zadaniem ekonomisty jest studiowanie warunków, w których dochodzi do realizacji tych dążeń. Warunki te przyjmują postać rynków, na których dochodzi do wymiany dóbr i usług po cenach ustalanych w kategoriach pieniężnych. Bywa jednak i tak, że niektóre dobra, np. związki małżeńskie czy korzyści z przestępstw, nie są przedmiotem „tradycyjnej” wymiany handlowej. Ludzie, chcąc zdobyć to, na czym im zależy, płacą za możliwość realizowania potrzeb zasobami niematerialnymi, takimi jak wysiłek, poświęcony czas i zaniechane możliwości. Becker nazywa je "cenami-cieniami” (ang. shadow prices), a mechanizm koordynujący wymianę takich dóbr - „rynkiem-cieniem” (ang. shadow-markets).

Beckerowski homo oeconomicus kalkuluje zatem oczekiwane korzyści w rozmaitych sferach życia. Idea ta spotkała się z krytyką z wielu stron. Socjologowie krytykowali Beckera za - ich zdaniem - sprowadzanie motywacji człowieka do kalkulacji korzyści i „ekonomizację” celów rodziny. Na konferencjach ekonomiści wyśmiewali go nawet wprost, np. za traktowanie w modelach dzieci jako dóbr konsumenckich (wywiad w: Swedberg, 1990); z kolei nurty feministyczne atakowały go za „niedorzeczne" sankcjonowanie tradycyjnego podziału ról w rodzinie (Bergmann, 1996). Tymczasem stanowisko Beckera było bardzo uporządkowane i konsekwentne: różnorakie zmienne psychologiczne i socjologiczne należy do modelu wprowadzać dopiero wtedy, gdy bazowe założenia są niewystarczające. Przykładowo analiza opłacalności przestępstw dla ich sprawcy prowadzi do spójnych wniosków, dla których niepotrzebne stają się wyjaśnienia w kategoriach kształtu czaszki, dziedziczenia biologicznego, wychowania czy rozczarowania społeczeństwem (Becker, 1968). 
Podejście Beckera odrzuca, obecną w rozważaniach socjologicznych i w ramach ekonomii normatywnej, ideę racjonalności substancjalnej na rzecz racjonalności instrumentalnej. Analizie i ocenie podlega tu sposób wykorzystania dostępnych środków i wymiana szeroko rozumianych dóbr, a nie ludzkie dążenia. Nie mówi się tu, co ma motywować ludzi, i nie sugeruje - co niesłusznie zarzucali Beckerowi niektórzy jego oponenci - że ludzie kierują się tylko własnym interesem. Ludzie maksymalizują użyteczność niezależnie od tego, czy są samolubni, altruistyczni, lojalni, złośliwi czy masochistyczni (Becker, 1992).

Założenie Beckera o racjonalności wyborów ludzkich stanowi naturalny kontekst dla pytania o jego stosunek do ekonomii behawioralnej. Okazuje się, że nie widział on w niej żadnej alternatywy dla teorii racjonalnego wyboru i uważał, że ekonomii behawioralnej brakuje „dialogu między teorią a danymi”. Jej obserwacje nie są osadzone w jakimś uniwersalnym modelu, a jedynie wyrywkowo pokazują naruszanie założeń o racjonalności. Jako takie stanowią więc co najwyżej podpowiedź uwzględnienia dodatkowych zmiennych. Na przykład wprowadzenie dyskontowania hiperbolicznego do analizy ekonomicznej nie zmieniło gruntownie pozostałych jej założeń. Występowanie błędów poznawczych nie podważa koncepcji homo oeconomicus: jeśli jedni je popełniają, a drudzy potrafią to wykorzystać, to konkurencja między tymi drugimi zniweluje efekty ograniczonej racjonalności. Człowiek ma prawo wierzyć, że w rzucie kostką najczęściej wypada dziesięć oczek; racjonalny przeciwnik będzie korzystać na błędzie dopóty, dopóki ma monopol na grę. Gdy takich racjonalnych przeciwników będzie więcej, konkurując i proponując coraz wyższą rekompensatę, sprawią, że efekt błędnego przekonania zniknie (Herfeld, 2012).

\section{WYBRANE OBSZARY BADAŃ}

Dyskryminacja na rynku pracy (Becker, 1957). Chronologicznie pierwszym ze zjawisk, które Becker poddał analizie ekonomicznej, była dyskryminacja na rynku pracy. O dyskryminacji mówimy wtedy, gdy ludzie są niesprawiedliwe traktowani z powodu uprzedzeń rozumianych jako preferencje dyskryminującego odnośnie do rasy, wyznania, wieku lub płci. W najprostszym ujęciu - wynagrodzenie można wyrazić jako $Y=X \times \beta+\alpha \times Z$, gdzie $X$ oznacza produktywność pracownika, $\beta$ - technologię produkcji, $Z$ - przynależność do grupy podlegającej dyskryminacji, a $\alpha<0$ - nasilenie stopnia dyskryminacji.

W dotychczasowych rozważaniach wskazywano oczywistą rzecz, że na dyskryminacji tracą jej ofiary. Już w rozprawie doktorskiej Becker wykazał, że dyskryminacja 
zmniejsza także dochody i zyski producentów oraz pracodawców. Decydując się na nią, swoimi uprzedzeniami i ignorancją ograniczają oni odpowiednio rynek swoich towarów i usług oraz dostęp do wykwalifikowanych pracowników. Dyskryminacja jest zatem ekonomicznie szkodliwa również dla tych, którzy ją praktykują. Jeśli osoby dyskryminowane nie różnią się produktywnością pracy od niedyskryminowanych, dyskryminujący karzą siebie samych: ich uprzedzenia działają jak „klin podatkowy”. Becker wykazał, że dyskryminacja jest mniej powszechna w branżach konkurencyjnych, a bardziej - w regulowanych. W warunkach wolnorynkowych, dyskryminujący pracodawcy i producenci dobrowolnie ograniczają swoje zyski i udział w rynku, a firmy, w których do dyskryminacji nie dochodzi, korzystają z arbitrażu rynkowego i wyższej krańcowej produktywności osób zatrudnianych. Dyskryminacja szkodzi bardziej tam, gdzie grupy dyskryminowane są liczniejsze. Mechanizmem tym Becker tłumaczył kres apartheidu w Afryce Południowej, gdzie koszty dyskryminacji dla ludności białej były relatywnie wyższe niż w Stanach Zjednoczonych, w których biali byli kilkukrotnie liczniejsi i posiadali większe zasoby kapitału ludzkiego i fizycznego.

Kapitat ludzki (Becker, 1962, 1964). Idea kapitału ludzkiego nie była nowa, ale Becker jako pierwszy zwrócił uwagę, że jest on podobny do fizycznych środków produkcji - takich jak fabryki i maszyny - w tym, że inwestowanie weń zwiększa jego zasoby. Są dwa rodzaje kapitału ludzkiego: ogólny, który stanowi np. umiejętność czytania i pisania oraz wiedza nabywana w szkole, na uniwersytecie lub mediach, oraz kapitał specyficzny, który tworzą np. umiejętności i doświadczenie charakterystyczne dla specyficznej branży lub danego przedsiębiorstwa. Kapitał specyficzny daje pewne przewagi na rynku, ale jest ryzykowny, ponieważ trudno go wykorzystać poza daną firmą lub branżą w razie jej schyłku.

Ludzie zwiększają zasoby kapitału ludzkiego, poświęcając nań swoje pieniądze i czas. Jego zasoby nie są stałe, jak np. ziemi uprawnej, lecz rosną wraz ze wzrostem populacji; rośnie także stopa zwrotu z inwestycji w kapitał ludzki. Uwzględnienie kapitału ludzkiego w analizach wyjaśnia, dlaczego nie sprawdziły się przewidywania Thomasa Malthusa o przeludnieniu (sytuacji, gdy zasoby - głównie ziemi uprawnej i surowców naturalnych - nie nadążają za wzrostem populacji), a jego założenie o geometrycznym wzroście populacji, przynajmniej w odniesieniu do społeczeństw z dużymi zasobami kapitału ludzkiego, okazało się błędne. Skorelowany z kapitałem ludzkim postęp technologiczny sprawił, że - mimo czterokrotnego zwiększenia się populacji globalnej od czasów Malthusa - standard życia, ogólnie rzecz biorąc, wzrósł. Korzystanie z urządzeń oraz żywności przetworzonej uwolniło czas, który można poświęcić na wykształcenie i zdobycie doświadczenia zawodowego. Postęp w sferze ochrony zdrowia i zwiększenie oczekiwanej długości życia sprawiły natomiast, że dłuższa edukacja ma szanse zwrócić się w przyszłości. Posiadanie wiedzy ogólnej i specjalistycznej stało się i opłacalne, i niezbędne dla zdobycia dobrze płatnej 
pracy. Gdy rosną płace, rośnie koszt alternatywny wychowania dzieci, a rodziny wielodzietne stają się bardziej kosztowne. Ponieważ z jednej strony trzeba (ze względu na wymagania rynku), a z drugiej można (ze względu na dłuższe życie) poświęcić więcej czasu, wysiłku i pieniędzy na edukację, ludzie odwlekają decyzję o założeniu rodziny. Gdy natomiast już się zdecydują na dzieci, więcej swojego czasu i pieniędzy inwestują w ich wychowanie i wykształcenie, dlatego rodziny nie są już tak liczne.

Decyzje w obrębie rodziny i matżeństwa (Becker, 1973, 1981). Becker porównał rodzinę i gospodarstwo domowe do małego przedsiębiorstwa, które wytwarza najbardziej podstawowe dobra, takie jak pożywienie, miejsce mieszkania i rozrywka. Dwa główne rodzaje kosztów ich zapewnienia to czas poświęcany na ich wytworzenie i konsumpcję oraz koszty pieniężne niezbędnych dóbr rynkowych. W tradycyjnych analizach ekonomicznych uwzględniano już czas spędzany w domu, rozważając wybory między czasem wolnym a pracą, ale to Becker jako pierwszy zwrócił uwagę na wymierne koszty związane z wykonywaniem prac domowych i wychowaniem dzieci, ponoszone przez niektórych członków rodziny - zwykle kobiety. Kosztami tymi są czas i wysiłek wkładane w prace domowe oraz utracone wynagrodzenie z pracy zarobkowej. W przeciwieństwie do Adama Smitha - Becker twierdził, że praca w domu ma wymierną wartość, zwiększając m.in. kapitał ludzki. Nawiązując do Ricardiańskiej teorii kosztów komparatywnych, Becker dowodził także, że decyzja o podziale ról może być najefektywniejszym sposobem alokacji materialnych i niematerialnych zasobów rodziny (Becker, 2009). Jednakże zwiększenie się majątku rodziny i wzrost jej kapitału ludzkiego sprawiają, że niekoniecznie opłaca się, by jeden członek rodziny całkowicie poświęcał się pracom domowym, w tym wychowywaniu dzieci. Wzrost płac i posiadane kompetencje zwiększają koszty utraconych możliwości, skłaniając go do decyzji o podjęciu pracy, a rodzinę - do wyboru mniej czasochłonnych produktów i dóbr, w tym do decyzji o modernizacji urządzeń domowych oraz korzystania z usług gastronomicznych i wychowawczych.

W ekonomicznej teorii małżeństwa Becker stawiał m.in. pytania o to, kiedy zawierane są małżeństwa, jak długo ludzie pozostają w związkach, kiedy jednostka zaprzestaje poszukiwań właściwego partnera (Becker, 1973). Rachunek krańcowych „cen-cieni” pokazał, że ludzie kończą poszukiwania, gdy oczekiwana wartość kolejnego kandydata zaczyna przekraczać czas, wysiłek i koszty materialne związane z poszukiwaniami. Poszukiwania są tym dłuższe, im bardziej zróżnicowani są kandydaci i im bardziej ludzie są mobilni. Ludzie są skłonni tym wcześniej zawierać małżeństwa, im więcej planują mieć dzieci, im wyższe mają dochody i im niższe mają wykształcenie. Wcześniej pobierają się także albo nadmierni pesymiści (z uwagi na niskie subiektywne szanse spotkania kogoś wartościowego), albo ci, którym się poszczęściło (i spotkali kandydata o wysokiej wartości), a później - nadmierni optymiści lub ci, którym zabrakło powodzenia. 
Zbrodnia i kara: ekonomiczna teoria decyzji (nie)moralnych (Becker, 1968). Inspiracją do zajęcia się ekonomiką przestępstw była dla Beckera sytuacja, gdy jako student musiał szybko zdecydować, czy dopuścić się wykroczenia, parkując na ulicy, czy spóźnić się na egzamin. Uwzględniając ryzyko otrzymania mandatu i jego wielkość, uznał, że bardziej mu się opłaca ponieść karę. Olśniło go wtedy, że podobnie kalkulować muszą też władze miasta, decydując o liczbie dokonywanych inspekcji. Zaintrygowało go pytanie o to, jakie są optymalne wybory z perspektywy władz i policji, a jakie z perspektywy osób naruszających prawo (Becker, 1992). Jak duże zasoby warto angażować i jakich kar używać, by to się opłacało społeczeństwu? Ile przestępstw i które z nich powinny pozostać bez kary, bo nie opłaca się ich ścigać? Pytania te mogą wzbudzać moralny niepokój, lecz dotyczą ważnej kwestii: nie tylko tego, jak niwelować straty spowodowane bezpośrednio przez przestępstwa, lecz także jak ograniczać zasoby i wysiłek społeczeństwa zaangażowane w ściganie przestępców, dochodzenie sprawiedliwości i wymierzanie kar. W kolejnych modelach Becker uwzględnia m.in. relacje między liczbą przestępstw, ich kosztem, wielkością i charakterem kar a skutecznością aresztowań i wyroków skazujących, wydatkami publicznymi na policję i sądy itp. Jednym z jego wniosków było np. to, że kary pieniężne są dla społeczeństwa zdecydowanie korzystniejsze niż pozbawienie wolności.

Przestępca, jeśli nie działa pod silnymi ograniczeniami moralnymi i etycznymi, waży, czy oczekiwana użyteczność korzyści Y majątkowych i psychologicznych z przestępstwa przewyższa oczekiwaną użyteczność niepowodzenia (zysku pomniejszonego o konsekwencje dla sprawcy) Y - $f$. Wielkości te zależą od prawdopodobieństwa zatrzymania, skazania i ukarania $p$, co można wyrazić - oczywistą w analizie decyzyjnej - oczekiwaną użytecznością decyzji $E U$ o popełnieniu przestępstwa jako: $E U=p \times U(Y-f)+(1-p) \times U(Y)$. Oczywistym wnioskiem jest to, że popełnianiu przestępstw można zapobiegać, zmieniając odpowiednio wielkość kary $f$ i podnosząc wykrywalność przestępstw $p$. Becker zauważa, że społeczności, które nie radzą sobie ze skutecznym wykrywaniem przestępstw, zwykle surowiej je karzą, natomiast w tych, w których skuteczność sądów i organów ścigania jest wysoka, wyroki za przewinienia są zwykle łagodniejsze. Zauważa też inną rzecz: jeśli ludzie mają odpowiednio wysokie dochody, atrakcyjność przestępczości spada.

Analizując zmiany krańcowej użyteczności $U$ pod wpływem zmian prawdopodobieństwa $p$ i kary $f$, Becker potwierdza to, co zdroworozsądkowo znane jest z doświadczenia: że przy innych czynnikach niezmienionych wzrost ryzyka $p$ zmniejsza skłonność do popełniania przestępstw silniej niż analogicznej wielkości zaostrzenie kary. Analizy Beckera prowadzą także do wniosków mniej oczywistych. Obydwie wielkości - prawdopodobieństwo kary i jej wielkość - muszą odzwierciedlać stopień powagi czynów przestępczych. Jeśli tak nie jest, to np. zaostrzanie kar w celu zniechęcania innych - co jest pożądane z perspektywy społeczeństwa - może wywołać 
skutki wręcz przeciwne. Stosowanie w niektórych stanach wyroku dożywotniego więzienia za trzykrotną recydywę zwiększa brutalność przestępstw. Choć surowość kary odpowiada tu liczbie przestępstw, to, paradoksalnie, jej stosowanie może skłaniać do eskalacji przemocy. Ponieważ krańcowa wartość kary za kolejne przestępstwo jest zerowa, przestępcy jest wszystko jedno, jak brutalny czyn popełni, przy czym ma powody, by „zapobiec” jego ujawnieniu.

Uzależnień teoria racjonalnego wyboru (Stigler i Becker, 1977; Becker i Murphy, 1988). Niektóre zachowania o poważnych przyszłych konsekwencjach są zakorzenione w decyzjach dokonanych wcześniej. Jest tak w przypadku uzależnień, dla których Becker, we współpracy ze Georgem Stiglerem, a później z Kevinem Murphym, zaproponował dość intrygujące wyjaśnienie mechanizmu ich powstawania. O uzależnieniu mówimy wtedy, gdy użycie dobra zwiększa jego konsumpcję w przyszłości, co zarazem oznacza, że jego bieżąca użyteczność zależy zarówno od konsumpcji teraźniejszej, jak i przeszłej. Jeśli konsumpcja przeszła zmniejsza satysfakcję płynącą z konsumpcji bieżącej, wtedy uzależnienie jest szkodliwe i kapitał konsumpcyjny $S$ w momencie $n$ negatywnie zależy od przeszłej konsumpcji, $S\left(C_{n-1}, C_{n-2}, \ldots\right)$. Im więc ktoś częściej zażywał heroiny, tym coraz mniejszą radość będzie odczuwać za każdym następnym razem. Negatywna zależność kapitału $S$ od $\mathrm{C}_{j-1}$ sprawia, że jednostka ma skłonność do kompensowania satysfakcji zwiększoną konsumpcją bieżącą. Jeśli natomiast przeszła konsumpcja zwiększa użyteczność bieżącą danej rzeczy, jest korzystna - jako przykłady autorzy podają słuchanie muzyki klasycznej lub uprawianie joggingu.

Analizy Beckera pokazują, że nawet małe ilości uzależniającej rzeczy wzmacniają skłonność do jej przyszłej konsumpcji. Im silniej dana osoba dyskontuje przyszłe wydarzenia i im bardziej preferuje intensywne i natychmiastowe wzmocnienia, tym bardziej jest krótkowzroczna i decyduje się na kompensowanie utraty satysfakcji coraz większymi dawkami (Becker i Murphy, 1988). Dlatego jeśli nie ma istotnych przeciwskazań, np. medycznych, najskuteczniejsza terapia polega na nagłym i całkowitym odstawieniu przedmiotu uzależnienia. Patrząc z tej perspektywy, miłośnika sportów ekstremalnych, coraz bardziej ryzykującego własnym życiem, należałoby pozbawić możliwości ich uprawiania; od naukowca, wciąż gromadzącego kolejne informacje, literaturę i dane, stanowczo domagać się syntezy tego, co już ma (być może odcinając mu dostęp do Internetu, bibliotek i funduszy na badania). Ciekaw jestem, jak zdaniem Beckera należałoby oderwać nastolatka od smartfona lub komputera. Z jednej strony urządzenia te są źródłem silnej, natychmiastowej gratyfikacji i skłaniają ludzi do bezwiednego korzystania z nich; z drugiej - nie da się ich tak po prostu „odstawić”, choćby dlatego że w odpowiedzi na pandemię COVID-19 stały się obecnie praktycznie jedynym sposobem podtrzymania relacji rówieśniczych i zapewnienia dostępu do nauki. 


\section{BibliograFiA}

Becker, G.S. (1957). The economics of discrimination: an economic view of racial discrimination. University of Chicago.

Becker, G.S. (1962). Investment in Human Capital: A Theoretical Analysis. Journal of Political Economy, 70(5), 9-49.

Becker, G.S. (1964). Human Capital. 2nd edition. Nowy Jork: Columbia University Press.

Becker, G.S. (1968). Crime and Punishment: An Economic Approach. The Journal of Political Economy, 76(2), 169-217.

Becker, G.S. (1973). A Theory of Marriage: Part I. Journal of Political Economy, 81(4), 813-846.

Becker, G.S. (1976). The Economic Approach to Human Behavior. University of Chicago Press.

Becker, G.S. (1981). A Treatise on the Family. Harvard University Press.

Becker, G.S. (1992). The economic way of looking at life. Nobel Lecture, December 9, 1992. Pobrano ze strony: www.nobelprize.org/uploads/2018/06/becker-lecture.pdf.

Becker, G.S. \& Nashat, G. (1997). The Economics of Life: From Baseball to Affirmative Action to Immigration, How Real-World Issues Affect Our Everyday Life. McGraw Hill Professional.

Becker, G.S., \& Murphy, K. (1988). A theory of rational addiction. Journal of Political Economy 96(4), 675-700.

Bergmann, B.R. (1996). Becker's theory of the family: Preposterous conclusions. Challenge, 39(1), 9-12.

Herfeld, C. (2012). The Potentials and Limitations of Rational Choice Theory: An Interview with Gary Becker. Erasmus Journal for Philosophy and Economics, 5(1), 73-86.

Levitt, S.D. (2006, 16 kwietnia). Guity Becker roasts Gary Becker. Freakonomics. https://freakonomics.com/2006/04/16/guity-becker-roasts-gary-becker/

Stigler, G., \& Becker, G.S. (1977). De gustibus non est disputandum. American Economic Review, 67(2), 76-90.

Swedberg, R. (1990). Economics and Sociology: Redefining Their Boundaries: Conversations with Economists and Sociologists. Princeton University Press. 